\title{
Cultivar mixtures of processing tomato in an organic agroecosystem
}

\author{
Felipe H. Barrios-Masias • Marita I. Cantwell • \\ Louise E. Jackson
}

Published online: 15 December 2010

(C) The Author(s) 2010. This article is published with open access at Springerlink.com

\begin{abstract}
At an organic farm in California, managed biodiversity was manipulated by establishing a mustard cover crop (MCC) and fallow during winter, and after incorporation, tomato mixtures of one, three, and five cultivars were planted in the spring (1-cv, 3-cv, and 5-cv, respectively). It was hypothesized that cultivar mixtures may increase yields over a monoculture if disease pressure or nitrogen $(\mathrm{N})$ availability is affected by the previous cover crop. The monoculture $(1-\mathrm{cv})$ of the grower's preferred cultivar was compared with mixtures of it and other high-yielding cultivars in the region. Soil nitrogen, soil microbial biomass carbon (MBC), soil emissions of carbon dioxide $\left(\mathrm{CO}_{2}\right)$ and nitrous oxide $\left(\mathrm{N}_{2} \mathrm{O}\right)$, crop nutrient uptake, biomass, fruit quality, intercepted photosynthetically active radiation (PAR), and disease symptoms were measured. The MCC reduced soil $\mathrm{N}$ leaching potential during winter and immobilized soil $\mathrm{N}$ early in the tomato season as suggested by higher soil $\mathrm{MBC}$ and $\mathrm{CO}_{2}$ emissions. Tomatoes had higher PAR, aboveground biomass, fruit yields, and harvest index in the winter fallow than in
\end{abstract}

F. H. Barrios-Masias • L. E. Jackson $(\bowtie)$

Department of Land, Air and Water Resources, University of California Davis,

One Shields Avenue,

Davis, CA 95616, USA

e-mail: lejackson@ucdavis.edu

M. I. Cantwell

Department of Plant Sciences,

University of California Davis,

One Shields Avenue,

Davis, CA 95616, USA the winter MCC, likely due to higher $\mathrm{N}$ availability in the fallow plots after transplanting. All cultivar mixtures had fairly similar yield and shoot biomass within fallow and MCC, probably explained by the low genetic diversity among California modern tomato cultivars. However, at mid-season (75 days after planting (DAP)), the 3-cv mixture had higher shoot and fruit biomass, by $46 \%$ and $63 \%$, than the monoculture in the MCC, indicating some plasticity under lower $\mathrm{N}$ availability. In the fallow treatment, soil $\mathrm{CO}_{2}$ emissions were lower in the 3-cv mixture than the monoculture at 77 and 100 DAP. Tomatoes in the $3-\mathrm{cv}$ mixture were redder than the monoculture. The $3-\mathrm{cv}$ mixture thus had some minor advantages compared with the monoculture, but overall, there was little evidence of higher ecosystem functions from mixtures vs. monoculture. Further research on mixtures of processing tomatoes may only be warranted for conditions of higher environmental stress than occur in California organic farms or if specific genotypic traits become available such as for disease resistance or improved nutrient uptake.

Keywords Brassica cover crop · Fruit quality Nitrogen · Soil · Solanum lycopersicum L. · Sclerotium rolfsii Sacc

\section{Introduction}

In organically managed agroecosystems, higher temporal and spatial biodiversity within production fields can be achieved by crop rotations, mosaic cropping, 
and inter- and intraspecific crop mixtures (Skelsey et al. 2005; Smith et al. 2008). These practices are commonly used on organic farms due to their beneficial effects on nitrogen $(\mathrm{N})$ fixation, nutrient uptake and retention, transfer of nutrients between taxa, pest control, and productivity (Pimentel et al. 2005; Berntsen et al. 2006; Smukler et al. 2008). Many organic farms rely on the sustainable intensification of farm management practices that rely on renewable resources, ecological stability, and biodiversity (USDA-NOP 2009), to increase productivity and lessen environmental degradation (Vandermeer et al. 2002; Kremen 2005; Jackson et al. 2007).

Cultivar mixtures are a type of within-field diversification (Jensen 1952; de Vallavieille-Pope 2004). At present, their use has focused on disease management and yield. For example, wheat, barley, and rice are planted in intraspecific mixtures to prevent disease outbreaks and spread in the USA (WASS 2005), Germany (Finckh et al. 2000), and China (Meung et al. 2003). In a review of 100 studies of crop mixtures (mostly grains and legumes), yields were often slightly greater than the mean of the component cultivars (Smithson and Lenne 1996). Yield stability of crop mixtures can exceed that of their individual components across a range of soil types (Cowger and Weisz 2008). Nonetheless, farmers may be unwilling to risk lower yields in mixtures than in monocultures (Jensen 1952). It is often difficult to demonstrate that higher productivity occurs for mixtures than for the best-yielding monoculture, partly because so many different mixtures must be tested (Cardinale et al. 2006). Nevertheless, trait diversity in a mixture can improve the crop response to biotic or abiotic stress especially in low-input systems, where yields may be more susceptible to variation in resource availability (Newton et al. 2009).

Cultivar selection for mixtures depends on plant characteristics such as agronomic compatibility (Lopez and Mundt 2000), genotypic diversity (Mundt 2002), high yields, and marketability. The usual number of genotypes in a blend, i.e., cultivar mixture, tends to be around three (Mundt 2002). Modern, highyielding cultivars can perform well in mixtures especially when intraspecific interactions among different cultivars within a species are low and harvest can occur simultaneously (Phillips and Wolfe 2005). Competition for dominance and niche complementarity among cultivars can start from early plant development.
A cultivar's response in a mixture depends on the composition of a particular mixture and the surrounding environment (Gallandt et al. 2001). Thus, a specific cultivar can perform differently in various mixtures than in monoculture, such as for harvest index (Brim and Schutz 1968).

Cover crops are another means for increasing the temporal diversity in communities. Some of the benefits of cover crops are the control of weeds and diseases, higher yields, reduction of run-off and soil erosion, increased water infiltration in the soil, and uptake and immobilization of nutrients that otherwise could be lost from the system (Dabney et al. 2001; Snapp et al. 2005; Smith et al. 2008; Wang et al. 2008). Brassica cover crops, in addition, have been reported to have biofumigation effects after incorporation in the soil that decrease disease incidence in subsequent crops (Brown and Morra 1997). Nutrient uptake by crops and soil $\mathrm{N}$ retention are affected by the nutrient release from cover crops, which varies temporally, and depends on the quality of the cover crop residues, e.g., $\mathrm{C} / \mathrm{N}$ ratio (Wilke and Snapp 2008). Thus, the choice of a cover crop can affect ecosystem functions not only during their growth period, but also through the following cash crop season.

The central question of this study was: what are the benefits of a cultivar mixture compared with a monoculture in an organic agroecosystem? We made the following hypothesis based on the literature reviewed above: tomato cultivar mixtures may increase crop trait diversity when compared with the grower's preferred cultivar monoculture, and thus favor higher yields, especially if problems with disease occur, and if soil $\mathrm{N}$ availability is affected by a previous cover crop. This hypothesis was tested at an organic farm, with a set of commercially important processing tomato cultivars that were grown after either winter cover crop or fallow treatments to alter nutrient availability during the summer tomato growing season.

The specific objectives were to: (1) measure yield responses and nutrient uptake of a locally prevalent tomato cultivar, when grown in three different tomato communities, and after a winter cover crop vs. winter fallow treatment; and (2) assess the effects of temporal and spatial biodiversity (by the use of cover crop and cultivar mixtures) on nutrient availability and $\mathrm{N}$ losses, yields, tomato disease, and fruit quality. 
The discussion considers factors that could improve the benefits that may be derived from cover crops and mixtures of cultivars on organic farms.

\section{Materials and methods}

Field description

Our study involved participatory research with Rominger Brothers Farms, on a 26.5 ha field that had been in organic production for 12 years in Yolo County, California. The main commodities are processing tomato (Lycopersicon esculentum Mill. = Solanum lycopersicum L.) and oats (Avena sativa L.) as hay. Fall/winter cover crops are grown in most years. Processing tomatoes are grown every year on alternating fields, following organic standards (California Certified Organic Farmers http://www.ccof. org/), and utilize conventional tillage. The entire farm is mapped as a Tehama silt loam, a fine-silty, mixed, superactive, thermic Typic Haploxeralfs (USDA-SCS 1972). Total rainfall from November 2005 to April 2006 was $839 \mathrm{~mm}$ with over $40 \%$ of rain concentrated between December 17 and January 5. Average minimum and maximum temperatures during Fall, 2005, and Winter, 2006, i.e., the cover crop period, fluctuated between $6.0^{\circ} \mathrm{C}$ and $17.6^{\circ} \mathrm{C}$, respectively. During the tomato season, the minimum and maximum average temperatures were $15.4^{\circ} \mathrm{C}$ and $34.1^{\circ} \mathrm{C}$, respectively, with a minimum of $8.9^{\circ} \mathrm{C}$ and a maximum of $42.2^{\circ} \mathrm{C}$ between mid-June and midSeptember of 2006, and no rainfall occurred (CIMIS 2009).

\section{Cover crop and cultivar mixtures}

The experiment was conducted on a 0.8 -ha plot and received the same management as the rest of the field, e.g., irrigation and weeding. During Summer/Fall, 2005, the entire field was laser leveled, compost applied at a rate of $17 \mathrm{Mg}$ per ha $(\mathrm{C} / \mathrm{N}$ ratio of 9.7 ; composed of turkey manure and wine-grape solid residue), beds were prepared (1.52 $\mathrm{m}$ from furrow to furrow), and a mustard cover crop (MCC) (Brassica nigra [L.] Koch) was planted on November 3 with three planting lines per bed. A total of 16 plots, eight fallow and eight MCC plots (main plots), of $16 \mathrm{~m}$ long by $9 \mathrm{~m}$ wide (six beds per plot) were established in a randomized complete block design. The cover crop was mowed on April 26, 2006, and mustard residue was lightly incorporated in the top $10 \mathrm{~cm}$ of soil after 19 days, with sprinkler irrigation in between. Also the fallow fields were not tilled until this date. After cover crop incorporation, main plots were divided in three $5-\mathrm{m}$ subplots ( $15 \mathrm{~m}$ total) along the $16 \mathrm{~m}$ length; a $0.5-\mathrm{m}$ buffer strip from the main plot was left on each edge along the bed. Thus, a total of 48 subplots ( $5 \mathrm{~m}$ long by $9 \mathrm{~m}$ wide) were established in eight blocks with two main plots per block and three subplots per main plot. Each cultivar mixture (see below) was replicated eight times, once in every fallow and MCC main plot, for a total of 16 plots per mixture.

The processing tomato cultivars used in this experiment were: “AB-2", “CXD-179”, "H-2601", "H-8892", and "Red Spring". The cultivar mixtures (subplot treatments) consisted of the "choice cultivar" (AB-2) grown by the farmer in the entire field (1-cv); a mixture of the "choice cultivar" plus two more cultivars (CXD-179 and H-8892) used by the same farmer on his other fields $(3-\mathrm{cv})$; and these three cultivars plus two more (H-2601 and Red Spring) that were currently used by organic growers in California for a total of five cultivars (5-cv). All cultivars had the following characteristics, based on discussions with growers and nursery managers: high yielding and marketable for processing, grown commercially with similar amounts and timing of inputs, mid-maturity varieties, i.e., $\sim 125$ days from planting to harvest, and fruit quality that met industry standards. Cultivars within mixtures were arranged in subsets depending on the mixture, and the subsets were repeated continuously through the bed. The three cultivar mixtures (1-cv, 3-cv, and $5-\mathrm{cv})$ were manually transplanted after a mechanical planter had marked the planting rows. A total of 5760 seedlings were transplanted on May 18 and 19 on two rows per bed with plants separated $50 \mathrm{~cm}$ within each row, i.e., four plants per linear $\mathrm{m}$ on a bed or 2.66 plants $\mathrm{m}^{-2}$, the same density as used by the farmer. Between planting and harvest on September 7 and 8, field management included a mechanical weeding/cultivation, manual weeding, a sulfur application as a mite and disease preventive measure, and furrow irrigations at intervals of about 11 days for a total of nine irrigations of $88 \pm 22 \mathrm{~mm}$ event $^{-1}$ (Smukler et al. 2011). 
Soil sampling

During the cover crop period, soil was sampled on January 19, 2006, and a week previous to incorporation on April 17 ( -110 and -32 days after planting (DAP), respectively). During the tomato season, soil was sampled on May 25, July 17, and September 4 (7, 59, and 108 DAP, respectively). Sampling at 59 and 108 DAP was done on only three blocks (six main plots and 18 subplots total), due to time and labor limitations. Soil samples of about $500 \mathrm{~g}$ were taken from three depths $(0-15,15-30$, and $30-60 \mathrm{~cm})$, and were the composites of two cores per treatment. Wellmixed soil subsamples were measured for $\mathrm{KCl}-$ extractable nitrate $\left(\mathrm{NO}_{3}{ }^{-}\right)$and ammonium $\left(\mathrm{NH}_{4}{ }^{+}\right)$ with colorimetric determination using modifications of Miranda et al. (2001) and Foster (1995). Potentially mineralizable $\mathrm{N}$ (PMN) was determined from 7-day incubated soil at $37^{\circ} \mathrm{C}$ under anaerobic conditions, followed by $\mathrm{KCl}$ extraction and $\mathrm{NH}_{4}{ }^{+}$$\mathrm{N}$ colorimetric determination (Waring and Bremner 1964). Microbial biomass carbon (MBC) was analyzed for the $0-15$ - and $15-30-\mathrm{cm}$ depths using the fumigation extraction method, and total $\mathrm{MBC}$ was calculated by multiplying the flush of $\mathrm{C}$ by 2.64 (Vance et al. 1987). PMN and MBC were not determined for the January 19 sampling. Gravimetric soil moisture was determined at every sampling event.

Carbon dioxide $\left(\mathrm{CO}_{2}\right)$ and nitrous oxide $\left(\mathrm{N}_{2} \mathrm{O}\right)$ gas emissions were sampled after three irrigation events of the tomato crop at 28,77, and 100 DAP using closed, capped chambers for $30 \mathrm{~min}$ (Rolston 1986). Chambers were placed on the bed shoulder between the furrow and each individual cultivar of the mixture treatment. This location aimed to capture gas emissions from zones of high root and microbial activity during rapid changes in soil moisture after an irrigation event. Air samples were taken immediately after placing the chamber $(0 \mathrm{~min})$ and at $30 \mathrm{~min}$ after with air-tight glass syringes. Gas samples were stored in vacutainers for $<1$ week. $\mathrm{N}_{2} \mathrm{O}$ concentrations were analyzed on a gas chromatograph (HP 6890, Hewlett Packard, Palo Alto, $\mathrm{CA}$ ), and $\mathrm{CO}_{2}$ concentrations were determined using a GC with a thermal conductivity detector (HP 5890, Hewlett Packard, Palo Alto, $\mathrm{CA}$ ). Air and 1 and $7 \mathrm{~cm}$ soil depth temperatures were recorded with a digital thermometer (Fisher Scientific Inc., USA).
The soil solution was sampled with $60-\mathrm{cm}$ lysimeters (Soil Moisture Equipment Corp., Santa Barbara, CA) randomly placed on two different furrows within each subplot. A total of 36 lysimeters in 18 subplots in three blocks were used. Lysimeters were charged to $75 \mathrm{kPa}$ and sampled about 3 days after a rain or irrigation event. Samples were kept on ice in the field until laboratory measurements were taken for $\mathrm{pH}$ and $\mathrm{EC}$ on the same day and frozen for later analysis. Concentrations of $\mathrm{NO}_{3}{ }^{-}-\mathrm{N}$ were determined for all water samples at the end of the cropping season after thawing all samples on the same day as analysis was performed (see above).

\section{Plant sampling and measurements}

Cover crop aboveground biomass was sampled in both MCC and fallow treatments at -32 DAP. Three subplots of 60 by $50 \mathrm{~cm}$ were sampled in each main plot (MCC or fallow). The biomass of all three MCC planting rows was included by sampling $60 \mathrm{~cm}$ across the bed top. Biomass was separated into mustard, volunteer oats, and weeds, and a composite sample was made from the three subplots. Plants were rinsed and oven dried at $60^{\circ} \mathrm{C}$.

Tomatoes were sampled three times during the growing season at 39, 75, and 111 DAP. For the first two samplings, a set of either three (in the 1-cv and $3-\mathrm{cv}$ ) or five (in the 5-cv) plants per subplot were sampled. The "choice cultivar" (AB-2) within each mixture was always sampled individually. The other cultivars were sampled as a composite mixture. For the first two samplings, only four blocks were sampled, but all eight blocks were included at the time of harvest. At harvest, sampling was done on two beds per subplot along a $2.25 \mathrm{~m}$ strip (nine plants for the $1-\mathrm{cv}$ and $3-\mathrm{cv}$ mixtures), or $2.50 \mathrm{~m}$ strip (ten plants for the 5-cv mixture) for a total of 18 or 20 plants per subplot, respectively. Plants were clipped at the soil surface, sorted into vegetative and reproductive structures, and subsamples were oven dried at $60^{\circ}$ $\mathrm{C}$, weighed, and ground for nutrient analyses. For yield evaluation, fruits from each cultivar were recorded as total fruit and also sorted into only machine harvestable fruits. All plant samples were processed at the DANR Analytical Laboratory, UC Davis, for total $\mathrm{N}$ using a Nitrogen Gas Analyzer (LECO FP-528, St. Joseph, MI), and total K and P by $2 \%$ acetic acid extraction and microwave acid 
digestion, respectively, and quantitative determination by atomic absorption spectrometry or inductively coupled plasma-atomic emission spectrometry (Meyer and Keliher 1992).

Canopy light interception was measured at 35, 69, and 95 DAP using a portable-tube solarimeter with sensors for photosynthetically active radiation (PAR; AccuPAR-80, v. 4.5, Decagon Devices, Inc. Pullman, Washington). Measurements were taken at canopy intervals of $12.5 \mathrm{~cm}$ for the first sampling and $25 \mathrm{~cm}$ for the last two samplings. The bed length sampled was $1.25 \mathrm{~m}$ (i.e., five plants) in the $1-\mathrm{cv}$ and $5-\mathrm{cv}$ mixtures and $1.50 \mathrm{~m}$ (i.e., six plants) for the $3-\mathrm{cv}$ mixture to include equal representation of all cultivars in a mixture.

Disease evaluation for Sclerotium rolfsii Sacc. (Southern blight), a major problem in the entire field, consisted of individual assessment of plants in relation to disease symptoms at 74 DAP and harvest (111 DAP). Plants were scored on a scale from 1 to 5 , where 1 was $0 \%$ of the individual plant affected, 2 (25\%), $3(50 \%), 4(75 \%)$, and 5 (100\% or dead).

Postharvest quality and fruit composition were evaluated at 105 DAP by collecting a total of $25-50$ fruits per cultivar from at least six plants within a mixture. Fruits were stored at $10^{\circ} \mathrm{C}$ for 6 days, sorted, washed, weighed, and selected for evaluations (12 fruits per rep $\times 4$ reps). From each cultivar within a mixture, 12 fruits of marketable quality (no serious defects and no decay) and weights between 40 and $80 \mathrm{~g}$ were evaluated for fruit color, firmness, soluble solids (SS), titratable acidity, and $\mathrm{pH}$ (Mitcham et al. 2003). Fruit color was determined as $L^{*} a^{*} b^{*}$ color values with a reflectance colorimeter (Minolta CR300 color meter) and expressed as hue angle (hue decreases as fruit develops red color). Firmness was tested with a nondestructive tomato firmness device (Qualitest durometer) with values expressed as percent of maximum force (13 Newtons). SS were determined from samples frozen at $-20^{\circ} \mathrm{C}$, which were partially thawed, blended, filtered and measured on a digital refractometer. Titratable acidity (TA) was determined from 10-mL juice, titrated with $0.1 \mathrm{~N}$ $\mathrm{NaOH}$, and $\mathrm{pH}$ was read directly on a $\mathrm{pH}$ meter.

Statistical analysis

The experimental design was a complete randomized block design with a split-plot treatment structure.
Analysis of variance (ANOVA) was performed using the GLM procedure of SAS, Version 9.1 (SAS Institute, Cary, NC). The error term used for main plots, i.e., fallow and MCC treatments, was specified as "e $=$ main plot $\times$ block". Shapiro-Wilk $W$ test for normal distribution and Levene's test for homogeneity of variance were used to test that data fulfilled the ANOVA assumptions. Data was transformed as necessary when assumptions were not met. TukeyKramer HSD test was used to determine significant differences among treatments at $P<0.05$.

\section{Results}

Winter fallow and mustard cover crop treatments

Available inorganic $\mathrm{N}$ as $\mathrm{NH}_{4}{ }^{+}-\mathrm{N}$ and $\mathrm{NO}_{3}{ }^{-}-\mathrm{N}$ differed between the fallow and MCC treatments, with greatest differences between treatments after cover crop incorporation and tomato transplanting (Fig. 1a). The $\mathrm{NO}_{3}{ }^{-}$pool was $<1 \mathrm{~g} \mathrm{~N} \mathrm{~m}^{-2}$ (0-60-cm depth) during the winter period, and increased in the spring and summer to $>3 \mathrm{~g} \mathrm{~N} \mathrm{~m}^{-2}$, with mean values as high as $5.4 \mathrm{~g} \mathrm{~N} \mathrm{~m}^{-2}$ in the mid-tomato season. This high value corresponds to pools of 2.2, 1.8, and $1.4 \mathrm{~g} \mathrm{~N} \mathrm{~m}^{-2}$ at 0-15-, 15-30-, and 30-60-cm depths, respectively. More specifically, the winter MCC decreased $\mathrm{NO}_{3}{ }^{-}-\mathrm{N}$ prior to cover crop incorporation and at 7 DAP. Ammonium was highest in the winter (2.5 $\mathrm{g} \mathrm{N} \mathrm{m}^{-2}$ ), and then decreased to approximately $1 \mathrm{~g} \mathrm{~N} \mathrm{~m}^{-2}$ prior to cover crop incorporation and after tomato transplanting. At 7 DAP, soil $\mathrm{NH}_{4}{ }^{+}-\mathrm{N}$ was slightly higher for the MCC treatment, and later remained in the same range for both fallow and $\mathrm{MCC}$ treatments.

Soil MBC during the tomato growing season was generally higher in the MCC treatment (Fig. 1b). In the $0-15-\mathrm{cm}$ soil layer, MBC values fluctuated more than at the 15-30-cm depth (data not shown). Results are presented as the composite values for both depths. Differences were found at 7 DAP, with $>20 \%$ increase in MBC for the MCC treatment, but not later in the season. Potentially mineralizable $\mathrm{N}$ decreased with time from $8.8 \mathrm{~g} \mathrm{~N} \mathrm{~m}^{-2}$ before cover crop incorporation (-32 DAP) to $4.1 \mathrm{~g} \mathrm{~N} \mathrm{~m}^{-2}$ by tomato harvest (108 DAP), but was not different between fallow and MCC treatments on any date (data not shown). Soil $\mathrm{CO}_{2}$ and $\mathrm{N}_{2} \mathrm{O}$ emissions were higher early in the 
$\checkmark$ - Winter Fallow

(a)

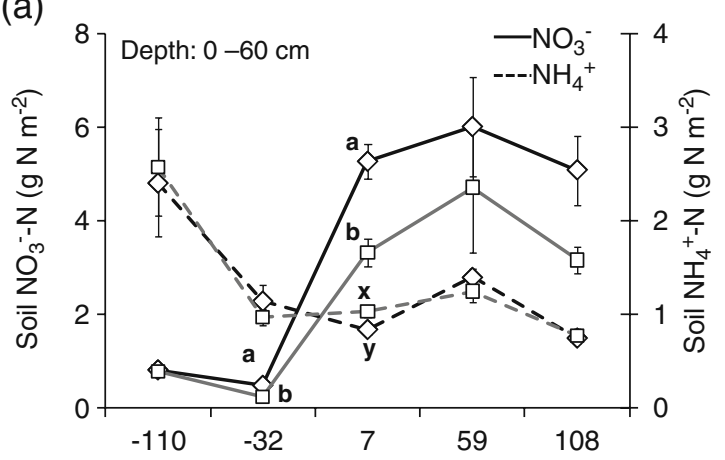

$-\square$ - Winter Mustard

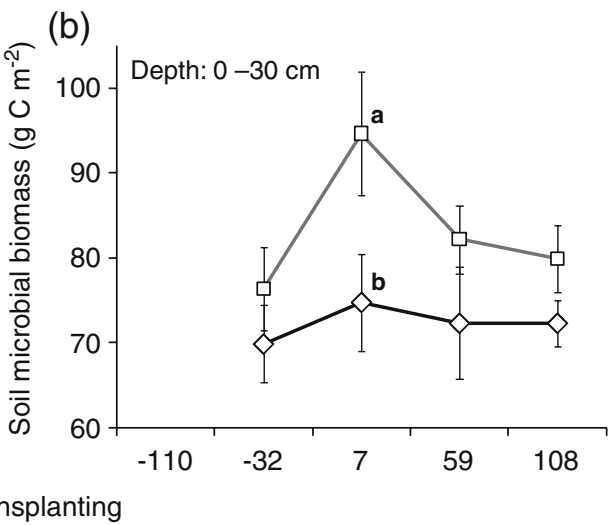

Fig. 1 Effects of a cover crop (winter mustard and winter fallow) on soil $\mathrm{NH}_{4}{ }^{+}-\mathrm{N}$ and $\mathrm{NO}_{3}{ }^{-}-\mathrm{N}$ at $0-60-\mathrm{cm}$ depth (a), and soil microbial biomass carbon (MBC) at $0-30-\mathrm{cm}$ depth (b) during the cover crop and the following tomato crop. Five sampling dates expressed as days after transplanting (DAP) of

tomato season (28 DAP) than at mid-season (77 DAP) and before harvest (100 DAP) (Fig. 2). The MCC treatment had higher $\mathrm{CO}_{2}$ emissions than the fallow at 28 DAP (139.9 and $222.5 \mathrm{mg} \mathrm{CO}_{2}-\mathrm{C} \mathrm{m}^{-2} \mathrm{~h}^{-1}$ for fallow and MCC treatments, respectively; $P<0.05$ ).

Aboveground plant biomass incorporated in the spring was $4.6 \pm 0.4 \mathrm{Mg} \mathrm{ha}^{-1}$ in the MCC plots and $0.8 \pm 0.1 \mathrm{Mg} \mathrm{ha}^{-1}$ in the fallow plots, which contained weeds and volunteer oats. This resulted in total aboveground plant $\mathrm{N}$ of $66.0 \pm 4.1$ and $18.0 \pm$ $2.0 \mathrm{~kg} \mathrm{~N} \mathrm{ha}{ }^{-1}$ in MCC and fallow treatments, respectively. Both biomass and $\mathrm{N}$ content were higher in the cover crop treatment $(P<0.0001)$. The $\mathrm{C} / \mathrm{N}$ ratio of the cover crop was about 30 at the time of sampling.

The tomatoes in the fallow treatment intercepted more PAR on all three sampling dates during the tomato growing season (Table 1). Harvestable fruit and total fruit biomass at 111 DAP were higher in the fallow treatment by $44 \%$ and $39 \%$, respectively (Table 1). Shoot biomass was similar in both treatments, but harvest index was significantly higher for the fallow treatment. Plant nutrient content $(\mathrm{N}, \mathrm{P}$ and $\mathrm{K})$ were similar on all dates, but at harvest, $\mathrm{N}$ tended to be higher $(P<0.10)$ for the winter fallow treatment (fallow, $11.5 \mathrm{~g} \mathrm{~N} \mathrm{~m}^{-2}$ and $\mathrm{MCC}, 9.6 \mathrm{~g} \mathrm{~N} \mathrm{~m}^{-2}$ ), and $\mathrm{P}$ content of non-harvestable fruit tended also to be higher (fallow, $0.6 \mathrm{~g} \mathrm{P} \mathrm{m}^{-2}$ and MCC, $0.5 \mathrm{~g} \mathrm{P} \mathrm{m}^{-2} ; P$ $<0.10$ ). Plants lost to $S$. rolfsii Sacc. were not different between main plots with a survival rate of $89 \%$ for the tomato crop. No MBC was determined at -110 DAP. Data show the mean \pm standard error. Means followed by different letters are significantly different at $P<0.05$. $n=8$ on DAP -110 , -32 , and 7. $n=9$ on DAP 59 and 108

fallow and $83 \%$ for the MCC (data not shown). Fruit were redder in the fallow treatment than the MCC (fallow, 38.9 hue and MCC, 39.8 hue; $P<0.05$ ), and fruit firmness tended to be higher in the MCC (fallow, 75.2\% and MCC, 77.2\%; $P=0.06$ ). Fruit weight, $\% \mathrm{SS}, \mathrm{pH}$, and $\mathrm{TA}$ were similar between tomatoes grown in fallow and MCC treatments (data not shown).

Tomato cultivar mixtures

Soil $\mathrm{NO}_{3}{ }^{-}$- and $\mathrm{NH}_{4}{ }^{+}-\mathrm{N}$, potentially mineralizable $\mathrm{N}$ and $\mathrm{MBC}$ did not differ among cultivar mixtures (data not shown). Soil gas emissions of the cultivar mixtures were not different, but there were main plot $\times$ subplot interactions (Fig. 2). Within the fallow treatment, $\mathrm{CO}_{2}$ emissions were higher in the monoculture than in the 3-cv mixture in the last two spot samplings (77 and 100 DAP). $\mathrm{N}_{2} \mathrm{O}$ emissions were higher before harvest (100 DAP) in the 5-cv mixture, but were quite low overall.

At harvest, vegetative growth and yields were similar for the three cultivar mixtures within each of the two winter treatments. Separate analyses by main plot were performed due to main plot*subplot interactions. Within the fallow treatment, cultivar mixtures had similar PAR interception and biomass production (Fig. 3). Within the MCC, some differences were observed. At 39 DAP, biomass in the MCC monoculture was higher than the MCC 5-cv 
Fig. 2 Soil $\mathrm{CO}_{2}(\mathbf{a}, \mathbf{b})$ and $\mathrm{N}_{2} \mathrm{O}(\mathbf{c}, \mathbf{d})$ emissions of one (1-cv), three (3-cv), and five (5-cv) tomato cultivar mixtures following a winter fallow (a, c) or winter mustard cover crop (b, d). Data obtained from three spot sampling dates during the tomato growing season (days after transplanting $(D A P))$. Data show the mean \pm standard error. Means followed by different letters are significantly different at $P<0.05 \quad(n=3)$. Uppercase letters for comparisons between sampling dates, and lowercase letters for mixtures within a sampling date

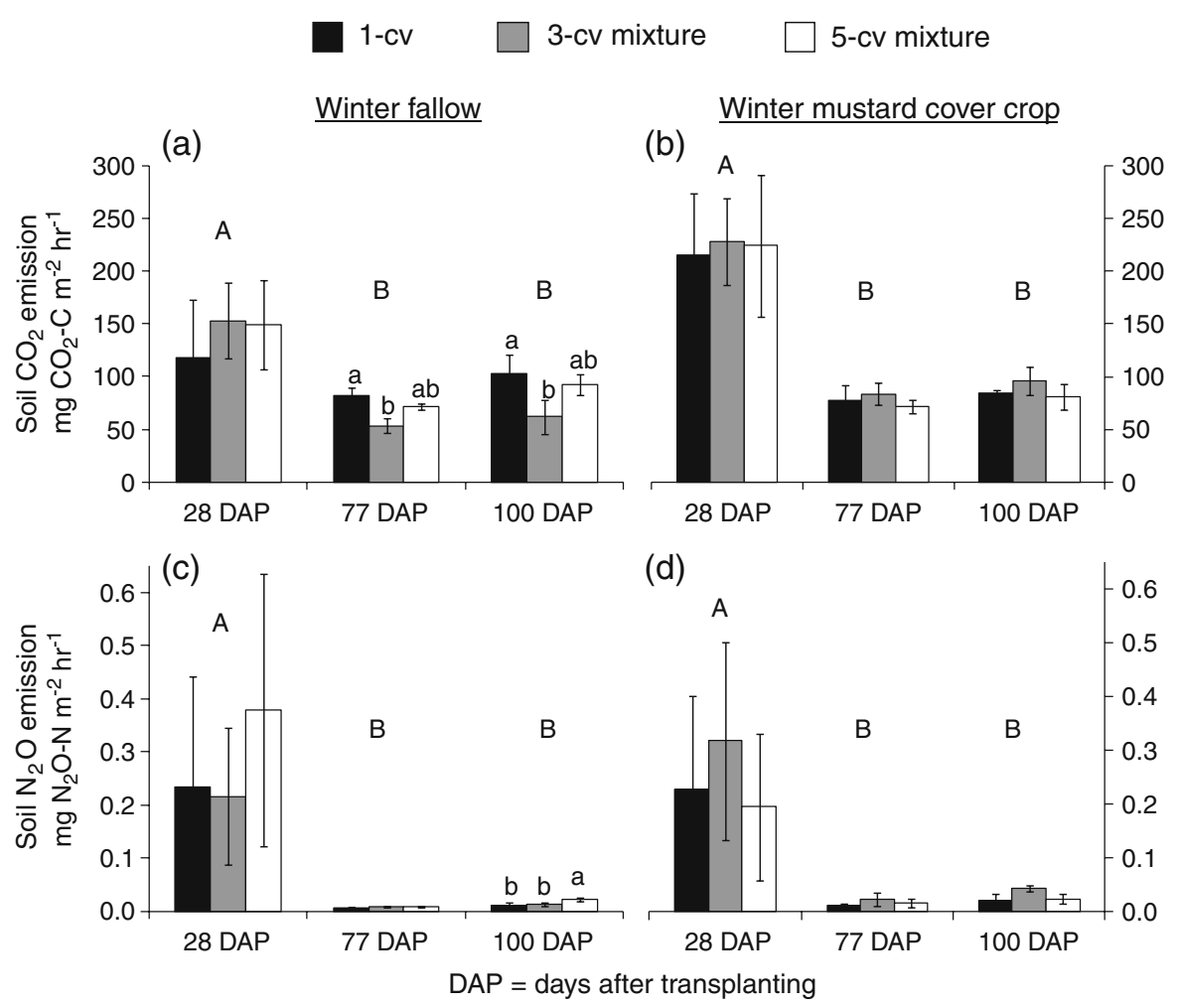

mixture. At 75 DAP, shoot and fruit biomass for the MCC 3-cv mixture were $46 \%$ and $63 \%$ higher than the MCC monoculture, but there were no differences by harvest (Fig. 3). Canopy PAR interception for the
MCC monoculture was significantly higher than the MCC 3-cv mixture at final harvest (Fig. 3).

Postharvest quality and compositional analyses showed differences in color and fruit weights among

Table 1 Percent photosynthetically active radiation (PAR) intercepted, tomato shoot and fruit biomass, harvest index and $\mathrm{N}$ uptake at early and mid-crop season, and harvest time for processing tomato mixtures after the two winter treatments

\begin{tabular}{|c|c|c|c|}
\hline \multirow[t]{2}{*}{$\mathrm{DAP}^{\mathrm{a}}$} & \multirow[t]{2}{*}{ Variables } & \multicolumn{2}{|c|}{ Cover crop treatment } \\
\hline & & Fallow mean $\pm \mathrm{SE}$ & Mustard mean $\pm \mathrm{SE}$ \\
\hline 35 & PAR intercepted (\%) & $20 \pm 1.0 \mathrm{a}$ & $15 \pm 0.9 \mathrm{~b}$ \\
\hline 69 & PAR intercepted (\%) & $46 \pm 1.0 \mathrm{a}$ & $39 \pm 1.3 b$ \\
\hline 95 & PAR intercepted $(\%)$ & $47 \pm 1.2 \mathrm{a}$ & $43 \pm 1.3 \mathrm{~b}$ \\
\hline 39 & Shoot biomass $\left(\mathrm{g} \mathrm{m}^{-2}\right)$ & $70 \pm 6.8$ & $54 \pm 4.7$ \\
\hline 75 & Shoot biomass $\left(\mathrm{g} \mathrm{m}^{-2}\right)$ & $246 \pm 17.4$ & $275 \pm 19.7$ \\
\hline 111 & Shoot biomass $\left(\mathrm{g} \mathrm{m}^{-2}\right)$ & $294 \pm 9.3$ & $274 \pm 13.2$ \\
\hline 75 & Total fruit $\left(\mathrm{g} \mathrm{m}^{-2}\right)$ & $122 \pm 12.5$ & $126 \pm 13.8$ \\
\hline 111 & Total fruit $\left(\mathrm{g} \mathrm{m}^{-2}\right)$ & $352 \pm 15.4 \mathrm{a}$ & $252 \pm 15.1 \mathrm{~b}$ \\
\hline 111 & Harvestable fruit $\left(\mathrm{g} \mathrm{m}^{-2}\right)$ & $234 \pm 14.7 \mathrm{a}$ & $162 \pm 15.6 \mathrm{~b}$ \\
\hline 111 & Aboveground $\mathrm{N}\left(\mathrm{g} \mathrm{N} \mathrm{m}^{-2}\right)$ & $12 \pm 0.4$ & $10 \pm 0.4$ \\
\hline 111 & Harvest index & $0.36 \pm 0.02 \mathrm{a}$ & $0.30 \pm 0.01 \mathrm{~b}$ \\
\hline
\end{tabular}

Data show the mean \pm standard error for all cultivar mixture treatments, since no differences were observed amongst them. Means followed by different letters are significantly different at $P<0.05 . n=24$, except on DAP 39 and 75 when $n=12$

${ }^{a}$ Days after transplanting 
Fig. 3 Aboveground biomass (shoots and fruits; a, b) and percent interception of photosynthetically active radiation $(\mathbf{c}, \mathbf{d})$ of cultivar mixtures conformed of one (1-cv), three (3-cv), and five (5-cv) tomato cultivars. Data shown by mainplots: winter fallow (a, c) and winter mustard cover crop (b, d). Data obtained from three sampling dates during the tomato growing season (days after transplanting $(D A P))$. Data represent the mean \pm standard error. Means followed by different letters are significantly different at $P<0.05$. $n=8$ except on DAP 39 and 75 when $n=4$

$1-c v$ 3-cv mixture 5-cv mixture

(a)

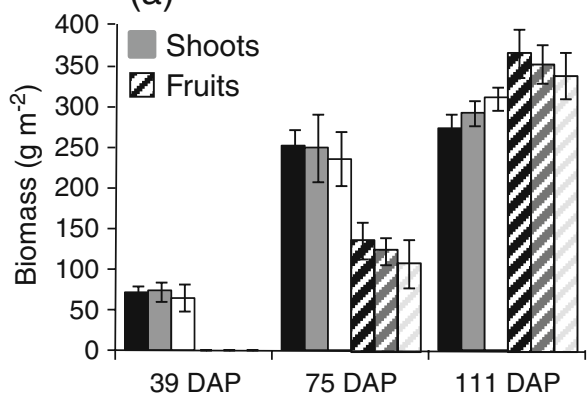

(c)

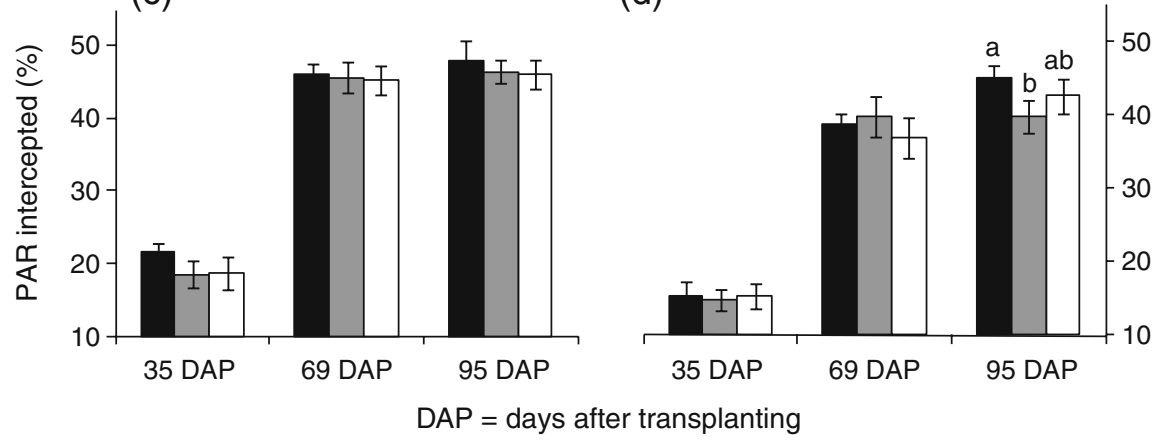

(b)

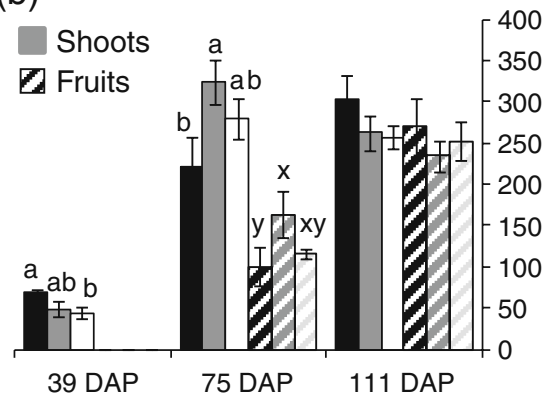

(d)
Winter mustard cover crop

'choice cultivar' in the different mixtures. The choice cultivar fruit were redder in the fallow than the MCC treatment (39.6 and 41.3 hue, respectively).

\section{Discussion}

At this organic farm, cultivar mixtures did not result in increased yields compared with the monoculture chosen by the farmer, even under conditions of low $\mathrm{N}$ availability and disease pressure. Unexpectedly, the $1-\mathrm{cv}, 3-\mathrm{cv}$, and $5-\mathrm{cv}$ treatments were quite similar in terms of nutrient uptake, light interception, shoot and fruit biomass. This suggests that trait diversity was low, with little differentiation in resource use or disease resistance. The cover crop increased soil $\mathrm{N}$ retention before and after its incorporation, reducing potential losses of soil $\mathrm{NO}_{3}{ }^{-} \mathrm{-N}$, but decreasing tomato yields due to an apparent initial period of high microbial $\mathrm{N}$ immobilization after cover crop incorporation. Organic farms typically rely on higher biodiversity to enhance ecological functions (Hole et al. 2005; IFOAM 2005; Badgley and Perfecto 2007), but this study suggests that the application of 
Fig. 4 Biomass accumulation of the 'choice cultivar' in tomato mixtures of one (1-cv or choice cultivar in monoculture), three (3-cv), and five $(5-\mathrm{cv})$ cultivars at three different days after transplanting $(D A P)$. Shoot biomass $(\mathbf{a}, \mathbf{b})$ and total and harvestable fruits $(\mathbf{c}, \mathbf{d})$. Data shown by mainplots: winter fallow $(\mathbf{a}, \mathbf{c})$ and winter mustard cover crop $(\mathbf{b}, \mathbf{d})$. Data obtained from three sampling dates during the tomato growing season (days after transplanting $(D A P))$. No fruits present at 39 DAP. Data represent the mean \pm standard error. Means followed by different letters are significantly different at $P<0.05 . n=4$ on 39 and 75 DAP. $n=8$ on 111 DAP
Choice cultivar $\square$ Choice cv in 3-cv mixture $\square$ Choice cv in 5-cv mixture Winter fallow Winter mustard cover crop

Shoot biomass, i.e., stems and leaves (a)

(c)

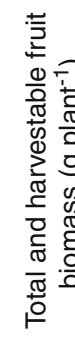

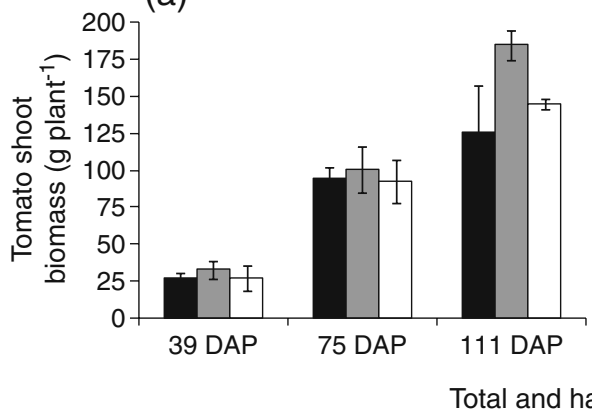

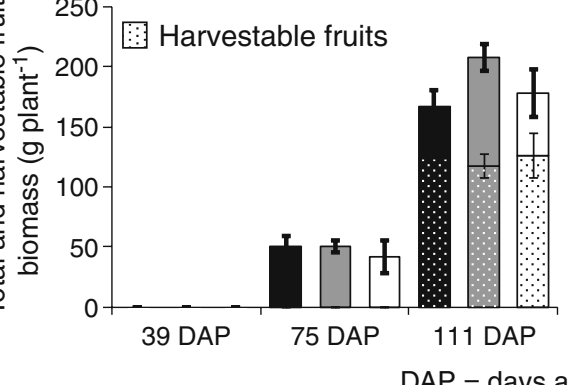

(b)

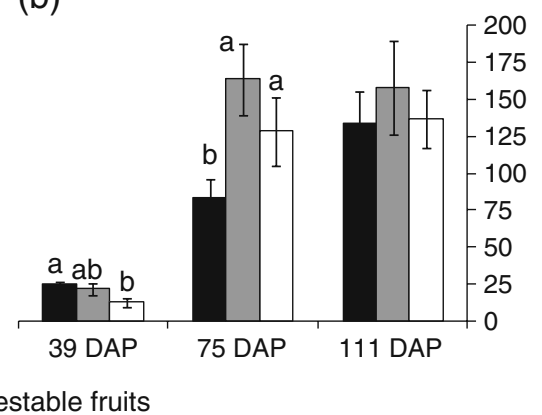

(d)
- 250

Harvestable fruits

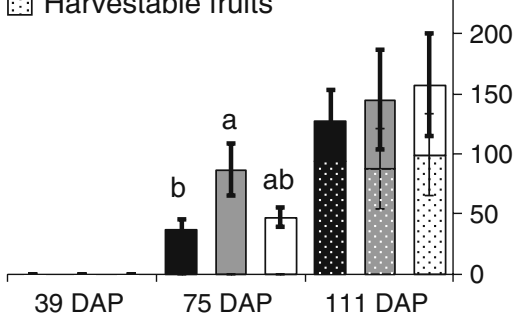

these concepts requires an understanding of the specific traits that enhance complementarity, the complexity of plant-plant and plant-soil interactions, and the potential benefits under fluctuating environmental conditions.

\section{Cultivar mixtures}

The lack of significant differences between the mixtures and the monoculture in crop performance and resource utilization may be the result of reduced genetic diversity in California modern tomato cultivars. Processing tomatoes are specifically bred for a compact canopy and determinate growth to facilitate mechanical harvest, and improved varieties usually result from crosses of already existing varieties (Tanksley and McCouch 1997; Jones et al. 2007). Thus, a narrow genetic diversity may have limited the potential for niche differentiation and complementarity that could have given mixtures an advantage over the monoculture.

Commercial cultivars are developed for their performance in monocultures but not for their agronomic response in cultivar mixtures (Worster and Mundt 2007; Newton et al. 2009). Testing the best performing mixture becomes challenging because of the large number of possible combinations that a group of cultivars can generate. In this study, the five cultivars would have generated 26 different combinations. The mixtures were assembled from currently used cultivars with high agronomic compatibility, but with no prior knowledge of the cultivars' performance in mixtures. Similarly, for wheat mixtures assembled based on cultivar characteristics and monoculture performance, yields never exceeded the highest yielding monoculture even under $\mathrm{N}$ limitation at an organic farm, even though component cultivars differed in early seasonal vigor, height, leaf area index, and time to maturity (Kaut et al. 2009). Some studies have found that different spatial arrangements of agricultural crops in mixtures (wheat and clover) also have an effect on biomass productivity (Worster and Mundt 2007), but it is unlikely that it would have occurred here due to the similarity of the cultivars used.

Identifying the best-yielding monoculture is easier than finding a mixture that outperforms the monocul- 
ture (Schmid et al. 2008). Choosing an overyielding monoculture rather than a cultivar mixture also depends on a grower's decision to either: (1) achieve the highest yield under higher risk, given that some resource deficiency or disease may occur; (2) secure a more stable yield in a fluctuating environmental situation, e.g., drought or heatwaves; or (3) assure high yields under conditions of consistently low environmental stress (Ceccarelli 1996; Phillips and Wolfe 2005; Kaut et al. 2009). For instance, mixtures with traits related to different flowering times in maize secured yields from terminal drought (Tilahun 1995). Cultivar diversity can increase yield stability by different cultivar response to stress conditions (Cowger and Weisz 2008; Newton et al. 2009). The tomato cultivars used in this study, however, were bred for high yields under the high-input, low-risk conditions of conventional, irrigated agriculture in California's Central Valley. Thus, traits that confer stress tolerance may be largely absent in all of the cultivars. One exception might be the differential response when $\mathrm{N}$ availability was limited due to delayed cover crop incorporation. The higher aboveground biomass of the MCC 3-cv mixture at 75 DAP may be the type of desired response in environments where nutrient source and temporal availability fluctuate, although it did not translate into higher productivity by harvest. In this case, the choice cultivar temporarily had higher biomass in the mixture than in the monoculture, suggesting that reduced competition may have allowed rapid exploitation of the limited soil N, generating a positive growth response. This suggests that research on competition and trait complementarity among components/cultivars in mixtures may reap benefits compared with exclusively focusing on overyielding monocultures in low-input systems (Vandermeer et al. 2002; Jackson et al. 2007).

All mixtures were equally affected by $S$. rolfsii, a soilborne pathogen for which no specific resistance has been reported from any of these cultivars. In fact, mixtures may be more conducive to suppression of airborne pathogens than soil pathogens, because innoculum is more pervasive due to long-term presence in the soil, and to continuous root-soil pathogen contact from the onset of crop establishment (Mundt 2002; de Vallavieille-Pope 2004; Newton et al. 2009).
Different rates of soil gaseous emissions have been related to specific cultivars, crop growth and developmental stage (Wang et al. 1997; Wang and Adachi 2000; Das and Baruah 2008). Methane emission of rice cultivars was related to higher root biomass, root exudates, and number of tillers because the plant acts as a conduit for methane transport (Wang et al. 1997; Wang and Adachi 2000). Gaseous emissions of 3-cv and 5-cv mixtures differed from the monoculture at some spot samplings under the fallow treatment. One possibility is that higher allocation to shoots and fruits, instead of roots, by some cultivars in the $3-\mathrm{cv}$ mixture may have reduced total root biomass and root exudates, compared with the monoculture, with lower $\mathrm{C}$ availability for microbial respiration. In contrast, $\mathrm{N}_{2} \mathrm{O}$ emissions were so low and differences so small that cultivar plasticity in allocation patterns have had little effect (Murphy et al. 2007).

The University of California statewide processing tomato variety trials conducted on conventionally managed farms show that monocultures of the five cultivars used in this study can vary in yield depending on location and year (UCCE 2009). For instance, the 'choice cultivar' was better yielding than two of the other four cultivars used in this study in 2007, yielded the same as two of these cultivars in 2006, and it yielded less than two of these cultivars for the year 2005, based on an average of at least five locations. Within years, cultivar yields varied by as much as $65 \%$, but as low as $35 \%$, depending on location. Thus, no single cultivar excelled across the range of environmental conditions for California processing tomatoes under conventional, high-input, irrigated agriculture. Overall, the cultivars appear to vary somewhat in response to annual variation in weather, local soils, or slight differences in management, but apparently not enough to generate differences in these mixtures.

In theory, stability of yields is higher when plants have complementary traits (Tilman et al. 2002). Greater productivity and more efficient resource use by a diverse plant community can occur due to high niche differentiation, which tends to increase with the number of plant taxa present (Loreau et al. 2001; Tilman et al. 2001). Canopy architecture, timing of fruit set, and above- and belowground allocation patterns can increase niche differentiation (Cowger and Weisz 2008). While not observed here, there is still the possibility that an advantage of tomato 
mixtures could occur with a more diverse set of cultivars especially in organic farming systems, which have greater fluctuation in $\mathrm{N}$ availability (Papendick and Elliott 1984), and less means available for disease control than conventional systems.

Fallow and mustard cover crop

The cover crop during the winter in this Mediterranean climate effectively reduced the potential for $\mathrm{NO}_{3}{ }^{-} \mathrm{N}$ leaching up until the time of incorporation. Late rains in the spring forced the grower to delay the incorporation of the MCC, and the maturity of the plants was the most likely reason for increased soil $\mathrm{N}$ immobilization potential, as suggested by higher $\mathrm{MBC}$ and $\mathrm{CO}_{2}$ emissions from the soil (Wyland et al. 1995).

The tomato crop performed better under winter fallow, likely due to higher $\mathrm{N}$ availability early in the tomato growing season. Early timing of $\mathrm{N}$ release from a cover crop was more important for corn yield, which has early $\mathrm{N}$ demand, compared with wheat for which $\mathrm{N}$ demand may be later (Smith et al. 2008). Negative effects of cover crops on $\mathrm{N}$ availability for the succeeding crop are often related to higher $\mathrm{C} / \mathrm{N}$ ratio (Wyland et al. 1995; Thorup-Kristensen et al. 2003; Berntsen et al. 2006; DuPont et al. 2009); a delay of 3 weeks in the incorporation of a nonleguminous cover crop can increase the $\mathrm{C} / \mathrm{N}$ ratio by as much as $50 \%$ (Vaughan and Evanylo 1998). Organic tomato yields decreased with delayed incorporation of a grass-legume cover crop, while legumes alone as a cover crop with a lower $\mathrm{C} / \mathrm{N}$ ratio, did not affect yields (Madden et al. 2004).

Despite these problems that occurred in an unusually wet spring, cover crops must still be considered as a key element for organic vegetable production (Martini et al. 2004; Lenzi et al. 2009). Practices to deal with large amounts of cover crop biomass include earlier mowing followed by immediate incorporation, which would have allowed decomposition to occur earlier in the year. Also, it may have been advantageous to delay tomato planting to match cover crop $\mathrm{N}$ release with crop $\mathrm{N}$ demand.

Biofumigation by Brassica spp. incorporation did not reduce the total plants lost to disease, as has also been seen in other field studies which considered soilborne pathogens like Verticillium dahliae Kleb., Fusarium spp., and Pseudomonas spp. (Scott and Knudsen 1999; Hartz et al. 2005). In mustard- incorporated soils, S. rolfsii populations were not different than non-planted soils (Njoroge et al. 2008). Positive effects on disease suppression depend on the amount of biomass, method of incorporation, tissue disruption, and timing related to pathogen life-cycle stage (Morra and Kirkegaard 2002; Matthiessen and Kirkegaard 2006; Snapp et al. 2007). Thus, the biofumigation effect of a cover crop is dependent on careful and precise management, and may need to be combined with other practices, e.g., rotations with nosusceptible crops, for a reduction in plant disease.

\section{Fruit quality}

Increased harvest quality benefits growers because of price premium incentives that processors establish in relation to color, $\mathrm{pH}$ and \%SS. Among the mixtures, fruit were redder (lower hue value) in the $3-\mathrm{cv}$ mixture, and this suggests that harvest quality can be improved. Cultivar traits, light exposure, and temperatures all affect tomato color (McCollum 1954; Dumas et al. 2003). Light exposure was measured as PAR interception, but no differences were found between mixtures. Tomatoes in the fallow treatment, however, had higher intercepted PAR and fruit were redder. Reduced canopy shading exposes fruits to direct sunlight, and fruit may reach temperatures above $32^{\circ} \mathrm{C}$, which reduces color development (McCollum 1954; Dumas et al. 2003).

Processing tomato cultivars differ in their final red color as they ripen from a pink to a red color (Garcia and Barrett 2006). Slightly different ripening times among tomato cultivars might cause a response in either direction, leading potentially to higher, more constant, or lower quality depending on the ratio of different components in a mixture. Mixtures of varieties that can be held in the field with high quality fruit would be advantageous for growers who are constrained in time by a contract with a processing facility.

\section{Conclusions}

This study suggests that processing tomato mixtures in California lack enough trait diversity to provide benefits, compared with monoculture, and this differs from work on other crop mixtures, e.g., wheat, barley, and maize. Developing mixtures that outperform the monoculture will likely require planning to combine cultivars 
with explicit traits that result in specific community interactions, niche complementarity, disease resistance, or higher resource utilization, such as spatial or temporal nutrient demands. Future research on mixtures of processing tomatoes for organic farms should target specific genotypic traits to meet such constraints.

Acknowledgments We thank Bruce Rominger from Rominger Brothers Farms for his help and willingness to conduct this research, Sean Smukler for his support and field data collection, and the USDA CSREES Organic Agriculture Research and Education Initiative Award 04-51106-02242 for funding.

Open Access This article is distributed under the terms of the Creative Commons Attribution Noncommercial License which permits any noncommercial use, distribution, and reproduction in any medium, provided the original author(s) and source are credited.

\section{References}

Badgley C, Perfecto I (2007) Can organic agriculture feed the world? Renew Agric Food Syst 22:80-82

Berntsen J, Olesen JE, Petersen BM, Hansen EM (2006) Long-term fate of nitrogen uptake in catch crops. Eur J Agron 25:383-390

Brim CA, Schutz WM (1968) Inter-genotypic competition in soybeans. 2. Predicted and observed performance of multiline mixtures. Crop Sci 8:735-739

Brown PD, Morra MJ (1997) Control of soil-borne plant pests using glucosinolate-containing plants. Adv Agron 61:167-231

Cardinale BJ, Srivastava DS, Duffy JE, Wright JP, Downing AL, Sankaran M, Jouseau C (2006) Effects of biodiversity on the functioning of trophic groups and ecosystems. Nature 443:989-992

Ceccarelli S (1996) Adaptation to low/high input cultivation. Euphytica 92:203-214

CIMIS (2009) California Irrigation Management Information System. Department of Water Resources. Office of Water Use Efficiency. Available at: http://www.cimis.water.ca. gov. Accessed 28 Jul 2009

Cowger C, Weisz R (2008) Winter wheat blends (mixtures) produce a yield advantage in North Carolina. Agron J 100:169-177

Dabney SM, Delgado JA, Reeves DW (2001) Using winter cover crops to improve soil and water quality. Commun Soil Sci Plant Anal 32:1221-1250

Das K, Baruah KK (2008) Association between contrasting methane emissions of two rice (Oryza sativa L.) cultivars from the irrigated agroecosystem of northeast India and their growth and photosynthetic characteristics. Acta Physiol Plant 30:569-578

de Vallavieille-Pope C (2004) Management of disease resistance diversity of cultivars of a species in single fields: controlling epidemics. C R Biol 327:611-620

Dumas Y, Dadomo M, Di Lucca G, Grolier P (2003) Effects of environmental factors and agricultural techniques on antioxidant content of tomatoes. J Sci Food Agric 83:369-382
DuPont ST, Ferris H, Van Horn M (2009) Effects of cover crop quality and quantity on nematode-based soil food webs and nutrient cycling. Appl Soil Ecol 41:157-167

Finckh MR, Gacek ES, Goyeau H, Lannou C, Merz U, Mundt CC, Munk L, Nadziak J, Newton AC, de Vallavieille-Pope C, Wolfe MS (2000) Cereal variety and species mixtures in practice, with emphasis on disease resistance. Agronomie 20:813-837

Foster JC (1995) Soil nitrogen. In: Alef K, Nannipieri P (eds) Methods in applied soil microbiology and biochemistry. Academic, San Diego, pp 79-87

Gallandt ER, Dofing SM, Reisenauer PE, Donaldson E (2001) Diallel analysis of cultivar mixtures in winter wheat. Crop Sci 41:792-796

Garcia E, Barrett DM (2006) Evaluation of processing tomatoes from two consecutive growing seasons: quality attributes, peelability and yield. J Food Process Preserv 30:20-36

Hartz TK, Johnstone PR, Miyao EM, Davis RM (2005) Mustard cover crops are ineffective in suppressing soilborne disease or improving processing tomato yield. Hortscience 40:2016-2019

Hole DG, Perkins AJ, Wilson JD, Alexander IH, Grice F, Evans AD (2005) Does organic farming benefit biodiversity? Biol Conserv 122:113-130

IFOAM (2005) IFOAM basic standards for organic production and processing. IFOAM (Institutional Federation of Organic Agriculture Movements). Available at: http:// www.ifoam.org/. Accessed 24 Nov 2009

Jackson LE, Pascual U, Hodgkin T (2007) Utilizing and conserving agrobiodiversity in agricultural landscapes. Agric Ecosyst Environ 121:196-210

Jensen NF (1952) Intra-varietal diversification in oat breeding. Agron J 44:30-34

Jones CM, Rick CM, Adams D, Jernstedt J, Chetelat RT (2007) Genealogy and fine mapping of Obscuravenosa, a gene affecting the distribution of chloroplasts in leaf veins and evidence of selection during breeding of tomatoes (Lycopersicon esculentum; Solanaceae). Am J Bot 94:935-947

Kaut A, Mason HE, Navabi A, O’Donovan JT, Spaner D (2009) Performance and stability of performance of spring wheat variety mixtures in organic and conventional management systems in western Canada. J Agric Sci 147:141-153

Kremen C (2005) Managing ecosystem services: what do we need to know about their ecology? Ecol Lett 8:468-479

Lenzi A, Antich D, Bigongiali F, Mazzoncini M, Migliorini P, Tesi R (2009) Effect of different cover crops on organic tomato production. Renew Agric Food Syst 24:92-101

Lopez CG, Mundt CC (2000) Using mixing ability analysis from two-way cultivar mixtures to predict the performance of cultivars in complex mixtures. Field Crops Res 68:121132

Loreau M, Naeem S, Inchausti P, Bengtsson J, Grime JP, Hector A, Hooper DU, Huston MA, Raffaelli D, Schmid B, Tilman D, Wardle DA (2001) Ecology_biodiversity and ecosystem functioning: current knowledge and future challenges. Science 294:804-808

Madden NM, Mitchell JP, Lanini WT, Cahn MD, Herrero EV, Park S, Temple SR, Van Horn M (2004) Evaluation of conservation tillage and cover crop systems for organic processing tomato production. Horttechnology 14:243-250 
Martini EA, Buyer JS, Bryant DC, Hartz TK, Denison RF (2004) Yield increases during the organic transition: improving soil quality or increasing experience? Field Crops Res 86:255-266

Matthiessen JN, Kirkegaard JA (2006) Biofumigation and enhanced biodegradation: opportunity and challenge in soilborne pest and disease management. Crit Rev Plant Sci 25:235-265

McCollum JP (1954) Effects of light on the formation of carotenoids in tomato fruits. Food Res 19:182-189

Meung H, Zhu YY, Revilla-Molina I, Fan JX, Chen HR, Pangga I, Cruz CV, Mew TW (2003) Using genetic diversity to achieve sustainable rice disease management. Plant Dis 87:1156-1169

Meyer GA, Keliher PN (1992) An overview of analysis by inductively coupled plasma-atomic emission spectrometry. In: Montaser A, Golightly GW (eds) Inductively coupled plasmas in analytical atomic spectrometry. VCH Publishers, New York, pp 473-505

Miranda KM, Espey MG, Wink DA (2001) A rapid, simple spectrophotometric method for simultaneous detection of nitrate and nitrite. Nitric Oxide-Biology and Chemistry 5:62-71

Mitcham B, Cantwell M, Kader A (2003) Methods for determining quality of fresh commodities. Perishable Handling Newsletter Issue No. 85

Morra MJ, Kirkegaard JA (2002) Isothiocyanate release from soil-incorporated Brassica tissues. Soil Biol Biochem $34: 1683-1690$

Mundt CC (2002) Use of multiline cultivars and cultivar mixtures for disease management. Annu Rev Phytopathol 40:381-410

Murphy DV, Stockdale EA, Poulton PR, Willison TW, Goulding KWT (2007) Seasonal dynamics of carbon and nitrogen pools and fluxes under continuous arable and leyarable rotations in a temperate environment. Eur J Soil Sci 58:1410-1424

Newton AC, Begg GS, Swanston JS (2009) Deployment of diversity for enhanced crop function. Ann Appl Biol 154:309-322

Njoroge SMC, Riley MB, Keinath AP (2008) Effect of incorporation of Brassica spp. residues on population densities of soilborne microorganisms and on dampingoff and Fusarium wilt of watermelon. Plant Dis 92:287294

Papendick RI, Elliott LF (1984) Tillage and cropping systems for erosion control and efficient nutrient utilization. In: Bezdicek DF, Power JF, Keeney DR, Wright MJ (eds) Organic farming: current technology and its role in a sustainable agriculture, ASA special publication \#46. Am Soc Agron Crop Sci Soc Am Soil Sci Soc Am. Madison. pp. $69-81$

Phillips SL, Wolfe MS (2005) Evolutionary plant breeding for low input systems. J Agric Sci 143:245-254

Pimentel D, Hepperly P, Hanson J, Douds D, Seidel R (2005) Environmental, energetic, and economic comparisons of organic and conventional farming systems. Bioscience 55:573-582

Rolston DE (1986) Gas flux. In: Klute A (ed) Methods of soil analysis Part I. Physical and mineralogical methods. Am Soc Agron and Soil Sci Soc Am, Madison, pp 1103-1119
Schmid B, Hector A, Saha P, Loreau M (2008) Biodiversity effects and transgressive overyielding. J Plant Ecol 1:95102

Scott JS, Knudsen GR (1999) Soil amendment effects of rape (Brassica napus) residues on pea rhizosphere bacteria. Soil Biol Biochem 31:1435-1441

Skelsey P, Rossing WAH, Kessel GJT, Powell J, van der Werf W (2005) Influence of host diversity on development of epidemics: an evaluation and elaboration of mixture theory. Phytopathology 95:328-338

Smith RG, Gross KL, Robertson GP (2008) Effects of crop diversity on agroecosystem function: crop yield response. Ecosystems 11:355-366

Smithson JB, Lenne JM (1996) Varietal mixtures: a viable strategy for sustainable productivity in subsistence agriculture. Ann Appl Biol 128:127-158

Smukler SM, Jackson LE, Murphree L, Yokota R, Koike ST, Smith RF (2008) Transition to large-scale organic vegetable production in the Salinas Valley, California. Agric Ecosyst Environ 126:168-188

Smukler SM, Jackson LE, O'Geen AT, Ferris H (2011) Environmental tradeoff assessment for best management practices on an organic farm in a Mediterranean-type climate. J Soil Water Conserv (in press)

Snapp SS, Swinton SM, Labarta R, Mutch D, Black JR, Leep R, Nyiraneza J, O’Neil K (2005) Evaluating cover crops for benefits, costs and performance within cropping system niches. Agron J 97:322-332

Snapp SS, Date KU, Kirk W, O’Neil K, Kremen A, Bird G (2007) Root, shoot tissues of Brassica juncea and Cereal secale promote potato health. Plant Soil 294:55-72

Tanksley SD, McCouch SR (1997) Seed banks and molecular maps: unlocking genetic potential from the wild. Science 277:1063-1066

Thorup-Kristensen K, Magid J, Jensen LS (2003) Catch crops and green manures as biological tools in nitrogen management in temperate zones. Adv Agron 79:227302

Tilahun A (1995) Yield gain and risk minimization in maize (Zea mays) through cultivar mixtures in semiarid zones of the rift-valley in Ethiopia. Exp Agric 31:161-168

Tilman D, Reich PB, Knops J, Wedin D, Mielke T, Lehman C (2001) Diversity and productivity in a long-term grassland experiment. Science 294:843-845

Tilman D, Knops J, Wedin D, Reich P (2002) Plant diversity and composition: effects on productivity and nutrient dynamics of experimental grasslands. In: Loreau $\mathrm{M}$, Naeem S, Inchausti P (eds) Biodiversity and ecosystem functioning: synthesis and perspectives. Oxford University Press, Oxford, pp 21-35

UCCE (2009) Vegetable Research \& Information Center. University of California Cooperative Extension. Available at: http://vric.ucdavis.edu/veg_info_crop/tomato.htm. Accessed 11 Nov 2009

USDA-NOP (2009) United States Department of Agriculture. National Organic Program. Available at: http://www.ams. usda.gov/AMSv1.0/NOP. Accessed 08 Sep 2009

USDA-SCS (1972) Soil Service of Yolo County, California. United States Department of Agriculture - Soil Conservation Service. Washington, DC, in cooperation with University of California Agricultural Experiment Station 
Vance ED, Brookes PC, Jenkinson DS (1987) An extraction method for measuring soil microbial biomass C. Soil Biol Biochem 19:703-707

Vandermeer J, Lawrence D, Symstad A, Hobbie S (2002) Effects of biodiversity on ecosystem functioning in managed ecosystems. In: Loreau M, Naeem S, Inchausti $\mathrm{P}$ (eds) Biodiversity and ecosystem functioning: synthesis and perspectives. Oxford University Press, Oxford, pp 157-168

Vaughan JD, Evanylo GK (1998) Corn response to cover crop species, spring desiccation time, and residue management. Agron J 90:536-544

Wang B, Adachi K (2000) Differences among rice cultivars in root exudation, methane oxidation, and populations of methanogenic and methanotrophic bacteria in relation to methane emission. Nutr Cycl Agroecosyst 58:349-356

Wang B, Neue HU, Samonte HP (1997) Effect of cultivar difference ('IR72', 'IR65598' and 'Dular') on methane emission. Agric Ecosyst Environ 62:31-40
Wang G, Ngouajio M, Warncke DD (2008) Nutrient cycling, weed suppression, and onion yield following Brassica and sorghum sudangrass cover crops. Horttechnology 18:68-74

Waring SA, Bremner JM (1964) Ammonium production in soil under waterlogged conditions as an index of nitrogen availability. Nature 201:951-952

WASS (2005) Washington agricultural statistics. USDA National Agricultural Statistics Service and Washington Agricultural Statistics Service, Olympia

Wilke BJ, Snapp SS (2008) Winter cover crops for local ecosystems: linking plant traits and ecosystem function. J Sci Food Agric 88:551-557

Worster CA, Mundt CC (2007) The effect of diversity and spatial arrangement on biomass of agricultural cultivars and native plant species. Basic Appl Ecol 8:521-532

Wyland LJ, Jackson LE, Schulbach KF (1995) Soil-plant nitrogen dynamics following incorporation of a mature rye cover crop in a lettuce production system. J Agric Sci $124: 17-25$ 